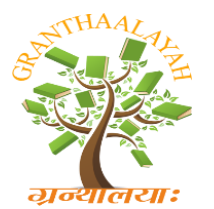

INTERNATIONAL JOURNAL OF RESEARCH GRANTHAALAYAH A knowledge Repository

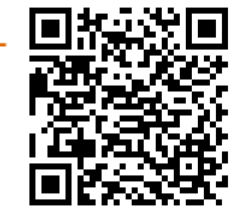

Management

\title{
POTTERY INDUSTRY AND ITS DEVELOPMENT BY EFFECTIVE MARKETING THROUGH INFORMATION AND COMMUNICATION TECHNOLOGIES (ICT)
}

\author{
S.V. Akilandeeswari ${ }^{1}$, Dr. C. Pitchai ${ }^{2}$ \\ ${ }^{1}$ Ph.D Scholar, Gandhigram Rural Institute -Deemed University, INDIA \\ ${ }^{2}$ Associate Professor, Gandhigram Rural Institute -Deemed University, Gandhigram-Dindigul, \\ INDIA
}

\begin{abstract}
Globalization has opened up the economy at a very high speed, as a result of that information technology has opened the sphere a global village and have facilitated global communications network that transcends national boundaries. Due to ICT there is a dramatic change in the society. Handicraft industry is the second largest industry which provides employment to rural and underemployed agricultural laborers. But large group of artisans are in the unorganized sectors like handicraft and cottage industry and these handicraft artisans are in inaccessible area of rural India. Majority of artisans are still bounded to traditional way of living so they are not enjoying the modern world benefits and adopted to modern scenario. These artisans are not access to available technology or participation and to promote for the contribution of societies development and these artisans are less engaged with Information and Communication Technologies (ICTs) than common man. Information and Communication Technologies are for everyone and handicraft artisans should equally benefit to the advantages offered by the technology to the products and processes.

Almost in all the States of the India, people are expert in producing handicraft items traditionally. The worth of Indian handicrafts in the international market was realized when the exports crossed Rs. 300,274.12 crores in 2012-13. The handicrafts sector has made considerable contribution to the Indian economy through exports. ICT brings success to marketing and export activities and production part of the craft. But knowledge on marketing technology was poor for artisans. So, an attempt has been made in this paper to bring out the problems and opportunities of artisans in the handicraft industry with the usage of ICT, and the opportunity for exporting to foreign countries and to help artisans improving their standard of living and thus the economy.
\end{abstract}

Keywords:

Artisans, Globalization, Liberalization, Export, Trade, Underemployment.

Cite This Article: S.V. Akilandeeswari, and Dr. C. Pitchai, "POTTERY INDUSTRY AND ITS DEVELOPMENT BY EFFECTIVE MARKETING THROUGH INFORMATION AND 
COMMUNICATION TECHNOLOGIES (ICT)" International Journal of Research Granthaalayah, Vol. 4, No. 4: SE (2016): 6-13.

\section{INTRODUCTION}

Knowledge is the only source which brings prosperity and liberates people from poverty and empowers them. Now, it is the era of web and networking technological world. Millions of dollars are being spent on Information and Communication Technologies and recent developments in the field of information and communication technology are tremendous. It brought the world as a single village.

By definition, Information and Communication Technologies are a diverse set of technological tools and resources to create, disseminate, store, bring value-addition and manage information. Interestingly, ICT, when used as a broad tool for amalgamating local knowledge incubated by the communities with information existing in remote databases and in public domain.

Handicraft industry is one of the important cottage industries which generate employment to the weaker section of the society in rural and urban area. But artisans are in the negative side of the environment. Only production process was given importance by artisans and produce in mass. They always depend on the middlemen for their marketing activities, so they are economically weak as they were exploited by the major players like entrepreneur/mastercrafts men. Economic development and its activities start with the reforms on knowledge on how effective marketing can be done with creative production. ICT can take a right product to the right customer which can be by effective marketing. Additionally, networking helps in interactive communication between artisans, Government bodies, NGOs, academic and research institutions and the society. ICT helps artisans, to take suitable steps to improve their craft, recognize their product and document their skill and to bring changes in marketing (Pitchai, 2013). So, to know how the artisans of handicraft can be improved with the help of Information and Communication Technology, an attempt has been made in this paper.

\section{IMPORTANCE OF HANDICRAFTS FOR SOCIETY}

Handicraft industry has helped the artisans to uplift economically so as to reduce poverty. Artisans can work in all seasons and they can produce craft in leisure time. Cost incurred for production is less as resources are available in local area. Because of this the industry is classified as small scale industry or household industry and even called as women-focused craft. The women can add-on to the family income by working from home. They can balance their home responsibilities and work. This industry earns from both the domestic and international market. The craft is produced on mass production so the artisans have fulltime work. Capital investment for this industry is less, so artisans can start their own business on small scale. Demand and supply for the craft can be managed, as this product could be stored in their respective home and sold whenever necessary, later. This Industry has evolved as one of the major revenue generator over the years for the artisans in India. 


\section{OBJECTIVE OF THE STUDY}

There is a huge demand for handicraft product, but general opinion is that these artisans do not make upto the expectations of the world market and standard. This prompts the researcher with number of questions. Whether these artisans are interested in modern marketing? Whether this artisan's possess knowledge on modern product design, adoption of new technology etc.? How ICT can help these artisans to upgrade for the global scenario? These questions need an answer and this study will try to bring out the facts. The main objectives of the paper is

1. To know the present socio-economic conditions of the pottery artisans.

2. To analyze the production and marketing of pottery products in the market economy.

3. To identify the avenues of adopting ICT among the pottery artisans

4. To suggest suitable strategy for sustenance and survival of the pottery artisans

\section{METHODOLOGY}

The primary data was collected directly from the pottery artisans through a well-structured interview schedule and focus group discussions with pottery artisans in Dindigul, Madurai, Sivagangai districts. Secondary data was collected from Handicraft Development Commissioner, reports on handicrafts by the Government of Tamilnadu and EPCH websites, reports of Planning commission, Handicrafts Marketing and Service Extension Center, Magazines, Journals, Periodicals, Newspapers, Previous work of scholars, Internet and Books.

The data was collected from all the artisans in the selected area by following Census Method as the artisans are small in number and they are in a particular place as a group. It is estimated that there are around 325 families who are carrying out the traditional pottery work till date. For the study, 41 families from Dindigul, Vedapatti, 122 families from Manamadurai and 142 families from Villacherry were chosen. So, all the pottery artisans were contacted for survey. The entire artisans family was contacted to find out the socio economic condition, production and marketing problems, knowledge on ICT for their improvement and their contribution towards the family improvement were analyzed by focused group discussion and interview.

The data collected through schedules was edited, coded, classified and tabulated to make necessary analysis and interpretation with the help of SPSS package of 16.0 version.

\section{ANALYSIS}

The gender of the respondents has been identified as one of the most important factors that influence the production capacity of the crafts (Lee, 2010). It also determines the status, roles and responsibilities of an individual in the family, the community and society and on the socioeconomic and cultural behavior. Women's contribution towards the production of crafts is more or less equal to male.

Education moulds and influences the mind of the young and the old and has the power to determine the purpose using the knowledge and the experience. It creates new attitude or generate a work force with new values, work ethics and new skills and positive orientation. Productivity of the respondents is an essential element of the new value and new behavior. It is 
one of the primary needs of all of human being (Sumner and Keller, 1946; National Knowledge Commission, India, 2008). Hence, basic education influences the productivity of pottery artisans. Formal education helps in rational decision making and effective execution of process (Ganesh Moorthi, 2000; Periaswamy, 2003) and boosts the productivity; so these variables are analyzed to know the knowledge level.

Table 1: Gender * Education Cross Tabulation

\begin{tabular}{|c|c|c|c|c|c|c|c|c|}
\hline \multicolumn{9}{|l|}{ Count } \\
\hline & & \multicolumn{6}{|l|}{ Education } & \multirow[b]{2}{*}{ Total } \\
\hline & & Primary & Higher & $\begin{array}{l}\text { Higher } \\
\text { Secondary }\end{array}$ & $\mathrm{UG}$ & PG & Illiterate & \\
\hline \multirow[t]{2}{*}{ Gender } & Male & 98 & 61 & 26 & 9 & 5 & 35 & 234 (77) \\
\hline & Female & 30 & 13 & 9 & 2 & 0 & 16 & $70 \quad(23)$ \\
\hline Total & & $128(42.11)$ & $74(24.34)$ & $35(11.51)$ & $11(3.62)$ & $5(1.64)$ & $51(16.78)$ & $304(100)$ \\
\hline
\end{tabular}

Source: Primary Data. Parentheses inside bracket denote the percentage value.

Table 1 reveals that out of 305 artisans, 234 ( 77 per cent) are male and 70 artisans ( 23 per cent) are female. Irrespective of the gender, every member of the family works together. The participation of the family members is so important in finishing the craft. Female members look after the production process while male members take care of finance, marketing and outside activities. Above all, the female members nourish the family and look after their children and during their leisure time they complete the production work. So this profession is most suited for the women in rural areas. They can work from house and earn their income out of their part time work as a pottery worker.

It is understood from the above table that 17 per cent of the respondents are illiterates. However, variation in educational status has also been noticed among them, 42 per cent of the respondents had primary education, 24 per cent of them have finished their secondary level school education, 11 per cent of them have higher secondary level and the remaining nine per cent of the respondents have completed their degree and post-graduation. So, education is not a prime criterion for the artisans to perform better in the business and become an entrepreneur. As the pottery work is traditional, only practice makes difference and perfects. But they have not brought any change in production process as well as technique which can simplify the work or different product. Still, the artisans are production same toys, pots, vase, statues and deities. These products are not up to the standard of the global wants. They crafts are so traditional which needs to be contemporary for the modern customer.

\section{ARTISANS POTTERY INCOME (MONTHLY)}

Income earned from a job depends on a number of factors like the place of work, timing of work, climatic conditions, group in which they are employed, technology used in the process of production, risk involved in the job and so on. Pottery income also depends on the season and functions and festivals. The particulars regarding monthly income of the respondents are given in Table 2. 
Table 2: Details of Respondent's Pottery Income (Monthly)

\begin{tabular}{|l|l|l|l|}
\hline S. No & Annual Income $($ Rs. $)$ & Number of Respondents & Percentage \\
\hline 1. & Below 5000 & 112 & 36.79 \\
\hline 2. & $5000-10000$ & 114 & 37.40 \\
\hline 3. & $10000-15000$ & 51 & 16.70 \\
\hline 4. & $15000-20000$ & 9 & 3.00 \\
\hline 5. & Above 20000 & 19 & 6.20 \\
\hline & Total & $\mathbf{3 0 5}$ & $\mathbf{1 0 0 . 0 0}$ \\
\hline
\end{tabular}

Source: Primary data

It is inferred from table 2, that more than one-third (36.7 per cent) of the respondents earn a monthly income of Rs.5000. And, 114 respondents income ranges between Rs.5,000 and Rs.10,000. Whereas, six per cent of the respondents earn more than Rs. 20,000 per month through the pottery occupation. These are the data which was given by the artisans when they market during the festival season. But regularly they don't know how much they earn. The articles sold daily or weekly will be spent for their house expense. As pottery are seasonal and used during particular time period, the pottery products are not fetching good prices in the market.

\section{PRODUCTION AND MARKETING OF POTTERY PRODUCTS}

Artisans of Pottery are suffering to sell their products in the market as they were doing direct marketing, whoever needs the products comes and purchase the product. This is one of the reasons for the failure of the product because it does not create need for the product among the customer. Only marketing and information technology, can take the products to wide range of customer out the production place with its usage. So to the study the marketing activities and its significance with the help of Chi-square and Factor analysis.

Table 3: KMO AND BARTLETT'S TEST

\begin{tabular}{|l|l|l|}
\hline $\begin{array}{l}\text { Kaiser-Meyer-Olkin Measure of Sampling } \\
\text { Adequacy. }\end{array}$ & .444 \\
\hline \multirow{4}{*}{ Bartlett's Test of Sphericity } & Chi-Square & 2990.844 \\
\cline { 2 - 3 } & df & 21 \\
\cline { 2 - 3 } & Sig. & .000 \\
\hline
\end{tabular}

The above table shows that the KMO value is 0.444 , which signifies that the factor analysis is useful with the data. The chi-square value for Bartlett's test of Sphericity is 2990.844 and the significant value is 0.000 which is significant at more than 99 percent level of confidence. This means that the data is very much suitable for factor analysis.

The next step in the process is to decide about the number of factors to be derived. The rule of thumb is applied to choose the number of factors for which 'Eigen values' with greater than unity is taken by using Principal Component Analysis method. 
Table 4: Factors and Variance Explained

\begin{tabular}{|l|l|l|l|}
\hline Factors & Eigen Value & \% of Variance Explained & Cumulative \% \\
\hline Techniques & 3.068 & 43.834 & 43.834 \\
\hline Effective & 2.019 & 28.848 & 72.681 \\
\hline
\end{tabular}

By performing factor analysis, 6 variables are reduced into 3 component factors. Each component factor includes some variables. Each component represents product details of sample about one particular aspects of promotion variable like technique statements under each factor explain features of such product. The 3 component product details factors which have Eigen value more than unity alone are taken for consideration. The three factors represent around 79 percent of total variance which is very significant and the remaining variance is explained by other variables. The first product details explains more than 45 percent of total variance and other 2 aspects of product details accounts for remaining 23 percentage of variance. The list of product details along with their Eigen values and percentage of variance explained are given in the below table.

The list of 3 component factors along with its label and variables (statements along with loading) included under these factors are listed below.

Table 5: Factor Loadings for Marketing Activities

\begin{tabular}{|l|l|l|}
\hline S. No & Factors & Loadings \\
\hline 1 & Personal selling & .791 \\
\hline 2 & Advertising & .483 \\
\hline 3 & Direct marketing & .804 \\
\hline 4 & Publicity & .742 \\
\hline 5 & Internet & .814 \\
\hline 6 & Others & .798 \\
\hline
\end{tabular}

The above table shows that this component factor of product details contains variables related to techniques used for promotion of marketing by the respondents have the highest loadings. They are not significant to the marketing activities. Artisans are failed in improving their marketing by using advertisement, personal selling and using internet and mobiles or publicity. Most of the artisans do not how to use latest mobiles or even heard of internet. They have not used any informative methods for marketing their products.

\section{HANDICRAFT ARTISANS AND ICT}

ICT (information and communications technology - or technologies) is an umbrella term that includes any communication device or application, encompassing: radio, television, cellular phones, computer and network hardware and software, satellite systems and so on, as well as the various services and applications associated with them (http://searchcio.techtarget.com/definition/ICT-information-and-communications-technology-ortechnologies, http: \What is ICT (information and communications technology - or technologies)__Definition from WhatIs.com.html).

ICT has benefited only the upper society of people as they have knowledge and understand it to adopt the new things quickly. These people enjoy the ICT facilitiesy and have developed 
themselves in their socio and economic status. The breadth of areas in which ICT's are continuously expanding. ICT in convergence with other forms of communication or other form of media have not been reached those artisans, still they do direct marketing or rely on the middlemen/agents for their marketing activities. Thereby they are not empowered themselves to participate in economic and social progress of the nation. Other issues like upgradation for new technology, empowerment in knowledge become even more significant and strategic for the survival of pottery artisans. They have not upgraded because of their locality and the society, economic and environmental situation of their communities. Artisans are powerless and poor access to information on many matters and this is because of their economic and geographical reasons. The main reason for poor access to information is illiteracy and lack of proper education. The wants and needs of pottery products are changing regularly, people are becoming health conscious, so the customer has to be targeted and position their product with proper use of technology like television, e-commerece, internet, mobiles and publicity (Akilandeeswari. 2014).

\section{CONCLUSION}

Globalization has changed the way people live, learn, work and relate. An explosion in the free flow of information and ideas has brought knowledge and its myriad applications to millions of people. It has created a number of new choices and opportunities for human efforts and showed way for good governance. Timely access to news and information can promote trade by effective advertisement and training/education. Information and knowledge are at the heart of efforts to strengthen tolerance, mutual understanding and respect for diversity. The Government need to do much by enhancing access to education and technology to the rural artisans and help them in adverstising their products by digital displays at governmnet offices, public places, market centers. NGO's have to train these artisans by forming Self Help Groups or Clusters and arrange for training classes at evening time and can create websities to promote the craft. Institutions can take up these artisans group and promote them under their Corporate Social Responsibility activity, help in marketing; technical guidance; training and technology upgradation, etc. ICT can improve the quality of life for poor rural communities who do not have access to these facilities.

\section{REFERENCE}

[1] Akilandeeswari, S.V and C. Pitchai. (2014). Improvisation of Pottery Industry and the rural Artisans by Marketing the Products on the Web, Innovative Facades in ECommerece, ISBN No: 978-93-81723-26-5, pp. 108-112.

[2] Ganeshmoorthi, S.(2000). Indigenous Knowledge on Post Harvest Practices, Unpublished thesis, Tamilnadu Agricultural University.

[3] Lee, B. (2010). University Students assessment of Entrpreneurial Environments. University of Nebraska-Lincoln: Unpublished thesis of Business Adminstration, pp. 2730.

[4] Regi, S. B. \& S, A. R. G. (2014). “A DESCRIPTIVE STUDY ON THE ROLE OF CONSUMER PSYCHOLOGY AND BEHAVIOUR IN PRODUCT PURCHASING”. Indian Streams Research Journal, 3.

[5] Periyasamy, M.(2003). Prosperity and Education, Kisan World, Vol. 30(2), Feburary 2003), p.20. 
[6] Pitchai. C. and S.V.Akilandeeswari. (2013). Strategy for Production and Marketing of Tamilnadu handicraft Products in a Competitive Environment. Research Explorer: Global Competitiveness-A Challenge for sustenance and Excellence,Vol.II, Issues. 1, pp.339-342.

[7] Summer, W.G and Keller, A.G. (1964). The Society of Science, New Heaven: Yale University Press, 1964.

[8] www.epch.nic.

[9] http://www.technologystudent.com/prddes1/ict1.html

[10] https://www.researchgate.net/publication/242021766_ICT_use_in_marketing_as_innovat ion_success_factor_enhancing_cooperation_in_new_product_development_processes_E ur_J_Innov_Manag

[11] http://www.techuk.org/training/marketing-and-sales-skills-training/item/582-marketingplanning-for-new-ict-challengers-sales

[12] http://summit.sfu.ca/item/796

[13] http://searchcio.techtarget.com/definition/ICT-information-and-communicationstechnology-or-technologies

[14] http: \What is ICT (information and communications technology - or technologies)_ Definition from WhatIs.com.html ) 